\title{
Evaluation of sarcopenia in long-lived elderly patients: comparison between the Muscle Mass Index and the Calf Circumference
}

\author{
Isadora Cecília Salgado Gama ${ }^{1}$, Sergio Chociay Junior ${ }^{1}$, Mariana de Paula Santana ${ }^{1}$, Nadine \\ Motta Figueiredo ${ }^{1}$, Nathália de Oliveira Andrade ${ }^{1}$, Gustavo Henrique Martins Rodrigues \\ Montalvão', Bruna Moretti Luchesi ${ }^{2}$
}

$\mathrm{T}$ he increase in life expectancy, observed in several countries, including Brazil, is due to improvements in living and health conditions and the epidemiological transition from the causes of morbidity and mortality, from infectious and parasitic diseases to chronic diseases. Furthermore, an increase in longevity, in addition to advances in science, with the improvement of diagnoses and the search for new treatments contributed to the increase in years lived $d^{1,2}$.

However, the aging process is associated with a decrease in organic functions over the years. Sarcopenia is considered a complex geriatric syndrome and is defined as an age-related decline in skeletal muscle mass and function $^{2}$. It is a major public health concern because it can result in functional decline, disability, falls, increased hospitalization costs, poor quality of life, and even deaths ${ }^{3}$. Although Dual-energy X-ray Absorptiometry (DXA) is the most used method to estimate the loss of muscle mass ${ }^{4}$ the high cost and low viability hinder its use in Primary Health Care (PHC). Methods such as Muscle Mass Index (MMI) and Calf Circumference (CC) can be used replacing DXA due to ease of access and application as well as low cost ${ }^{5}$.

The Academic League of Geriatrics and Gerontology, Três Lagoas Campus, Federal Univeristy of Mato Grosso do Sul designed and executed a research intending to evaluate several aspects in elderly people with extreme longevity. One of the variables analyzed was sarcopenia, which was evaluated and compared using MMI and CC. For this purpose, a cross-sectional and quantitative study was performed in 2019/2020, with $n=69$ individuals aged $\geq 90$ years, of both genders, users of the Unified Health System in the town of Três Lagoas - MS. A sociodemographic questionnaire containing gender, age, and years of schooling was applied. Anthropometric data (CC and MMI) were collected in triplicate. The skeletal muscle mass was determined using the formula of Lee and collaborators which considers age, body mass, gender, ethnicity and height ${ }^{5}$. The values of MMI of Janssen and collaborators were used as a reference to classify whether the nonagenarian or centenarians were sarcopenic or not ${ }^{6}$. For CC, a cutoff score $\leq 31$ centimeters was adopted as a sign of sarcopenia ${ }^{7}$.

The interviewed elderly had an average age of 93.5 years old, 1.3 years of schooling and $52.2 \%$ of the participants were women. The average $\mathrm{CC}$ was 31.2 centimeters, with $46.1 \%$ being considered sarcopenic patients according to this parameter. The average MMI was $5.1 \mathrm{~kg} / \mathrm{m}^{2}$, with $100 \%$ of the elderly patients being

Panels Awards - Primary Health Care - XXXIX COMU - Congresso Médico Universitário da FMUSP, nov. 2020.

1. Medical Student, Três Lagoas Campus, Federal University of Mato Grosso do Sul, Três Lagoas, Brazil. ORCID: Gama ICS - https://orcid.org/00000002-5278-8579; Chociay Junior S - https://orcid.org/0000-0001-8209-3834; Santana MP - https://orcid.org/0000-0003-1086-0808; Figueiredo NM - https://orcid.org/0000-0002-8284-8213; Andrade NO - https://orcid.org/0000-0003-1277-5551; Montalvão GHMR - https://orcid.org/0000-00018310-0469. E-mail: gustavo.montalvao@ufms.br, isadora.cecilia@ufms.br, sergio.chociay@ufms.br, mariana.p@ufms.br, nadine.motta@ufms.br, nathalia.andrade@ufms.br.

2. Undergraduate Medical School and Graduate Program in Nursing, Três Lagoas Campus, Federal University of Mato Grosso do Sul, Três Lagoas, Brazil. ORCID: Luchesi BM - https://orcid.org/0000-0002-0508-0818. E-mail: bruna.luchesi@ufms.br. 
considered sarcopenic through this method. There was no relationship between CC and MMI $(p=0.213)$.

The high rates of sarcopenia found, especially using MMI and the absence of a relationship between the CC and MMI highlights the need to use more reliable methods to evaluate sarcopenia in long-lived elderly people, since the identification from $\mathrm{CC}$, despite being easy and fast, may not be sensitive in this age group. These findings also lead to considering the use of more specific methods or those associated with other variables, such as Timed up and Go (TUG), for the evaluation of sarcopenia in the elderly aged

\section{REFERENCES}

1. Corrêa ERP, Miranda-Ribeiro A. Ganhos em expectativa de vida ao nascer no Brasil nos anos 2000: impacto das variações da mortalidade por idade e causas de morte. Cien Saude Coletiva. 2017;22(3):1005-15. doi: https://doi. org/10.1590/1413-81232017223.26652016.

2. Liguori I, Russo G, Aran L, Bulli G, Curcio F, Della-Morte D, Gargiulo G, Testa G, Cacciatore F, Bonaduce D, Abete P. Sarcopenia: assessment of disease burden and strategies to improve outcomes. Clin Interv Aging. 2018;13:913-27. doi:https://doi.org/10.2147/CIA.S149232.

3. Therakomen V, Petchlorlian A, Lakananurak N. Prevalence and risk factors of primary sarcopenia in communitydwelling outpatient elderly: a cross-sectional study. Sci Rep. 2020;10(1):19551. doi: https://doi.org/10.1038/s41598-020$75250-\mathrm{y}$.

4. Sergi G, Trevisan C, Veronese N, Lucato P, Manzato E. Imaging of sarcopenia. Eur J Radiol. 2016;85(8). doi:http://
90 years or over.

Future investigations should consider the importance of validating specific instruments for elderly people in extreme longevity, as they constitute a group that has unique characteristics. The screening, monitoring, and health promotion carried out by $\mathrm{PHC}$ teams can promote the improvement in the quality of life of elderly people in extreme longevity.

Conflicts of Interest Disclosures: the researchers claim no conflicts of interest.

dx.doi.org/10.1016/j.ejrad.2016.04.009 .

5. Lee K, Shin Y, Huh J, Sung YS, Lee I. Recent issues on body composition imaging for sarcopenia evaluation. Korean J Radiol. 2019;20(2):205-17. doi: http://dx.doi.org/10.3348/ kjr.2018.0479

6. Janssen I, Baumgartner RN, Ross R, Rosenberg IH, Roubenoff R. Skeletal muscle cutpoints associated with elevated physical disability risk in older men and women. Am J Epidemiol. 2004;15;159(4):413-21. doi: http://dx.doi.org/10.1093/aje/ kwh058

7. Brasil. Ministério da Saúde. Caderneta de saúde da pessoa idosa. 5a ed. Brasília: Ministério da Saúde; 2018. Disponível em: https://bvsms.saude.gov.br/bvs/publicacoes/caderneta saude_pessoa_idosa_5ed.pdf.

Received: 2020, December 03

Accepted: 2020, December 09 